\title{
STUDENTS' PERCEPTION ON HIGHER EDUCATION CRM POLICY
}

\author{
Verica Babić, Marko Slavković, \& Marijana Simić \\ Faculty of Economics, University of Kragujevac (Serbia)
}

\begin{abstract}
As a set of practices, customer relationship management (CRM) provides an integrated view of customers which have to ensure that each customer receives the highest level of service, and consequently enhance profitability of business. According to previous studies, different models have been developed in a wide range of settings. In order to achieve better results, many higher education institutions (HEIs) have recognized the importance of adopting CRM strategy. By implementing CRM initiatives, managers in HEIs, intend to increase performance, improve teaching process, and the relationship with their stakeholders. However, the literature on higher education (HE) marketing lacks theoretical models that are adapted to particular context of $\mathrm{HE}$ and the nature of their services. Thus, the adoption of CRM by HEIs request the use of appropriate instruments to acquire greater knowledge of the needs of students, in order to implement training courses and to provide services, which are tailored to their characteristics. The purpose of the article is to determine needs for customization of CRM approach in order to increase satisfaction of different students groups. The main goal of this paper is to examine CRM in a HE setting and difference in the level of satisfaction on existing CRM policy of HEIs. In order to achieve defined goal, the survey has been conducted among students in the Republic of Serbia, and 444 valid questionnaires were collected. Research findings reveal students' perceptions on CRM policy, implemented in HEIs. In addition, parametric $t$ test has been used in order to determine the difference in students' perception between male and female students, as well as between students at bachelor and master level of studies. Viewing students as customers, the obtained results should provide guidelines for achieving competitive advantage and improving a faculty's and university's ability to attract, retain and serve its customers. This paper, also, should be used by policy makers, as a recommendation in the HE sector to embrace investment in CRM and to highlight the relevance of implementing CRM strategy in HE setting.
\end{abstract}

Keywords: Customer relationship management, higher education, students.

\section{Introduction}

The growing importance of the third mission of university, which emphasizes its social dimension (Laredo, 2007), has significantly contributed to the attention of intangible asset of HEIs. Among the most valuable HEI's resources are a wide range of economic, political and institutional relationships, built and maintained between HEIs and their stakeholders (Ramírez-Corcoles et al., 2012, Veltri \& Silvestri, 2015, Pedro, Leitão \& Alves, 2019). By observing students as customers, as the most important stakeholders (Nair et al., 2007; Seeman \& O'Hara, 2006), the question arises which is the most effective approach applicable in the context of HEIs. Different marking tools have found their application in this context, and CRM can be presented as one of the possible means for developing relationships with students before, during and after teaching process (Badwan et al., 2017).

CRM has been widely applied in a corporate sector (Grönroos, 1996) and is one of the important approaches to sustaning an organization on a modern business environment, with the focus on identifying and delivering customized services to each customer (Ogunnaike, Tairat \& Emmanuel, 2014). In the context of higher education, CRM is also used (Tapp et al., 2004; Fletcher, Wheeler \& Wright, 1995; Peppers \& Rogers, 1997; Chen \& Ching, 2005) and is often the answer to challenges of HEIs faced with (Seeman \& O'Hara, 2006).

In view of the increasingly frequent application of the marketing concepts under the framework of HEI, in this paper students' perception on CRM in a HE setting is examined. Research conducted among 444 students aims to provide answers to the following research questions: 1) what is the perception of students about CRM policy in HEIs? 2) Is there a difference in perception between male 
and female students? 3) Is there a difference in perception between students at undergraduate studies and students in master studies? The purpose of the work is to establish, based on the identified differences in the perception of the existing CRM approach by different groups of students, guidelines for further customization of the CRM policy in order to increase student satisfaction during the course of study.

This paper starts with a definition of CRM, its implications for faculties and universities, and exploring students as customers. It then presents the research methodology and research results, which may be useful to gain a better understanding of the students' needs for CRM development. The last part refers to the contribution of conducted research and directons of future research.

\section{Literature review}

\subsection{Customer relationship management}

In literature numerous definitions of CRM concept are identified, with the implementation of this concept contributing not only to the performance of the organization, but also provides multiple benefits for customers. The basic assumption on which CRM is based is to provide one-to-one relationship with the customer (Seeman \& O'Hara, 2006) in order to understand the needs of customers and create a positive experience in relation to the given product / service, which is also of particular importance for keeping users, organizational growth and profitability (Badwan, Al Shobaki, Naser \& Amuna, 2017). Wali and Nkpurukwe (2008) define CRM as a customer acquisition process, customer retention, an increase in the number of users, thus ensuring the path towards achieving and sustaining competitive advantage. CRM is not just a marking tool, it is also an integral part of the business strategy. Therefore, CRM can be described as "a part of a customer-focused business strategy that aims to increase customer satisfaction and loyalty by offering customized service to each customer" (Seeman \& O'Hara, 2006; Wali, \& Wright, 2016).

CRM is a concept oriented towards creating an emotional relationship with customers, understanding their needs, distinguishing customers through market segmentation and loyalty analysis (Peppard, 2000). Berkowitz (2006) defines CRM as an effort, which organizations are investing to ensure an economic and long-term relationship with the consumer for well-being, not just organizations, but also customers. According to Karakostas et al. (2005), CRM is "a set of practices that provide a consolidated, integrated view of customers across all business areas to ensure that each customer receives the highest level of service". Therefore, one of the main goals of CRM is building trust between customers and organization with task that customers repeat purchase in the shortest future period (Ogunnaike et al., 2014).

Swift (2001) presents CRM as an organizational approach, with the crucial importance of communication, in order to enhance the satisfaction and loyalty of existing customers, but also attract more new customers. Therefore, employees must possess the necessary CRM skills in order to efficiently and effectively provide services in accordance with customer complaints and appeals (Gupta et al., 2013). And in this field, the contribution of marking tools is evident.

\subsection{CRM in higher education}

Higher education institutions (HEIs) are student-oriented organizations that pursue a wide range of student activities, such as admission, financial assistance, counseling, employment, and more (Nair, Chan, \& Fang, 2007). As such, HEIs are faced with the challenge of maintaining and increasing the number of newly enrolled students during one academic year. Although the number of high school students decreased during the 1980s and 1990s, the number of enrolled students grows year after year (McDonough, 1994; OECD, 2008). The trend of a significant increase in the number of students from the 1960 s to the 1990s was popularly described as "massification", which consequently led to the popularization of higher education in the modern developed world (Dolenec, 2006). However, even after attracting students and making a decision on enrollment, the challenge is to keep students focused on various student counseling programs and support activities for students in the job-seeking process (Seeman \& O'Hara, 2006).

On the presented challenges in the field of HE stands a use of CRM. This concept is widely implemented in the corporate sector (Grönroos, 1996; Nair et al., 2007). However, the numerous HEIs have already recognized that they should be flexible in meeting the different needs and preferences of students. Bearing in mind that most universities and faculties are qualified as medium-sized organizations, the importance of direct marketing and CRM approaches for improving entry rates has been proven (Tapp et al., 2004). Universities and faculties benefit from CRM implementation by: improving student-facing processes (Fletcher, Wheeler \& Wright, 1995), personalized communication with students (Peppers \& Rogers, 1997), information exchange between members of different departments (Chen \& Ching, 2005), and an increase the degree of student satisfaction (Kotler, 1997). 
Therefore, as in the corporate sector, managers and HEIs make efforts to adopt CRM initiatives, in order to increase performance, improve existing management practices and improve the relationship between HEIs and current and potential students (Badwan et al., 2017).

HEIs have different interest groups, and they need to act in order to meet their needs. Users, i.e. students (Nair et al., 2007) are classified as the most important stakeholders. A typical student usually visits the faculty several times before starting the teaching process. This includes their departure before faculty selection, a visit to register and another visit to pay fees and the purchase of textbooks. Since the development of the media and electronic registration systems has alleviated some of the problems and provided certain benefits, students continue to face numerous administrative tasks, which need to be completed while attending a particular HEI. When performing these tasks, a lot of time is spent waiting for a certain service, which reflects on satisfaction, but also on the retention rate of students at a particular faculty. One of the approaches that reduces a complexity of achieving these administrative tasks is the CRM approach, because it enables more efficient implementation of certain activities, such as registration at any time, payment of tuition fees, counseling and execution of requests, tailored to each individual customer, i.e, student (Seeman \& O'Hara, 2006).

\section{Methodology}

In addition to indicating the relevance of the CRM concept and the HEIs, the given theoretical framework is a starting point for researching student perceptions of CRM policy. Participation in the research were taken by students of graduate and master studies at HEIs, with a total sample of 444 respondents. Respondents were randomly selected, and data collection was carried out using a questionnaire, which was specially developed for this research. Respondents expressed their views on CRM policy on the 5-point Likert scale on (non)agreement. In order to obtain high internal consistency of the questionnaires for the items a results of previous research is used to measure CRM policy and relational capital (Sin, Tse \& Yim, 2005; Bontis, 1998, Wang, Wang \& Liang, 2014) which are additionally adapted to HEIs. By analyzing the structure of the sample, it was established: 365 graduate students and 79 master students; 83 male students and 361 female students. The software package SPSS was used for data processing. In order to make appropriate conclusions about student attitudes, descriptive statistics analysis, reliability analysis and parametric $t$ test were conducted.

\section{Findings and discussion}

Based on the displayed values of arithmetic mean and standard deviation, the conclusion is drawn that the highest degree of student aggregation is identified in terms of the relevance of knowledge acquired at the parent faculty compared to other faculties (Table 1). This statement indicates that the knowledge and quality of the teaching process are still the basic criteria of the faculty image, and it is clear that faculty management needs to pay special attention to processes of accreditation of study programs, but also to the teaching staff, who need be competent and ready for students to offer and transfer relevant knowledge in the given fields.

Table 1. Descriptive statistics and reliability analysis.

\begin{tabular}{|l|l|l|l|}
\hline Items & Cronbach's alpha =0,805 & Mean & $\begin{array}{l}\text { Standard } \\
\text { deviation }\end{array}$ \\
\hline RC1 & Students are satisfied with the teaching process. & 3,5045 & 0,96787 \\
\hline RC2 & Number of students' complaints is minimal. & 3,4302 & 1,05475 \\
\hline RC3 & $\begin{array}{l}\text { Faculty management develops cooperation with students and } \\
\text { former students. }\end{array}$ & 3,4054 & 1,07614 \\
\hline RC4 & Faculty has information about potential students. & 3,2725 & 1,03005 \\
\hline RC5 & $\begin{array}{l}\text { Faculty undertakes everything to meet the needs and wishes of } \\
\text { students. }\end{array}$ & 3,1554 & 1,09820 \\
\hline RC6 & $\begin{array}{l}\text { Acquired knowledge at this faculty has a higher value compared } \\
\text { to other faculties. }\end{array}$ & 3,5495 & 1,07286 \\
\hline
\end{tabular}

In order to determine the differences in the attitudes of male and female students, the second step was implementation of a parametric $t$ test (Table 2). Significant difference was observed in the case of the last two statements (RC5 and RC6). In the case of RC5 statement (i.e., Faculty undertakes everything to meet the needs and wishes of students.) it has been proven that female students show a higher level of consent, as in the case of RC6 (i.e., Acquired knowledge at this faculty has a higher value compared to other faculties.). 
Table 2. Results of t test for two independent samples (male and female).

\begin{tabular}{|l|l|l|l|l|}
\hline Items & $\begin{array}{l}\text { Male } \\
\text { M (SD) }\end{array}$ & $\begin{array}{l}\text { Female } \\
\text { M (SD) }\end{array}$ & t value & Sig. \\
\hline RC1 & $3,3012(0,93359)$ & $3,5512(0,97083)$ & $-2,131$ & 0.793 \\
\hline RC2 & $3,3494(1,14160)$ & $3,4488(1,03454)$ & $-0,773$ & 0.493 \\
\hline RC3 & $3,1807(1,02582)$ & $3,4571(1,08216)$ & $-2,118$ & 0.332 \\
\hline RC4 & $2,9759(1,08173)$ & $3,3407(1,00705)$ & $-2,934$ & 0.523 \\
\hline RC5 & $2,9639(1,01748)$ & $3,1994(1,11260)$ & $-1,767$ & $0.065^{*}$ \\
\hline RC6 & 3,2410 $(1,23555)$ & $3,6205(1,02063)$ & $-2,931$ & $0.023^{*}$ \\
\hline
\end{tabular}

Below are the results of the second t test (Table 3), which proved that there is no statistically significant difference between graduate and master students in the perception of CRM policy at the selected faculty.

Table 3. Results of t test for two independent samples (bachelor and master students).

\begin{tabular}{|l|l|l|l|l|}
\hline Items & $\begin{array}{l}\text { Bachelor students } \\
\text { M (SD) }\end{array}$ & $\begin{array}{l}\text { Master students } \\
\text { M (SD) }\end{array}$ & t value & Sig. \\
\hline RC1 & $3,4849(0,97660)$ & $3,5949(0,92707)$ & $-0,916$ & 0.605 \\
\hline RC2 & $3,4384(1,06630)$ & $3,3924(1,00534)$ & 0,351 & 0.462 \\
\hline RC3 & $3,4164(1,05182)$ & $3,3544(1,18795)$ & 0,464 & 0.107 \\
\hline RC4 & $3,2932(1,03726)$ & $3,1772(0,99691)$ & 0,907 & 0.306 \\
\hline RC5 & $3,1589(1,08787)$ & $3,1392(1,15175)$ & 0,144 & 0.682 \\
\hline RC6 & $3,4986(1,08340)$ & $3,7848(0,99577)$ & $-2,158$ & 0.441 \\
\hline
\end{tabular}

\section{Conclusion and guidelines for future research}

The obtained results show that in most of the observed statements there is no difference in the perception of CRM access between male and female students. A statistically significant difference was found in the domain of perceptions of the effort that the faculty invests in order to achieve a high level of student satisfaction. Female students expressed a higher level of consent, which indicates their higher level of satisfaction with actions that faculty invests to meet the needs and demands of students. These results have two practical implications: firstly, faculty management should identify the causes of lower satisfaction in the male student population in order to increase the overall level of student satisfaction, and secondly, female students are more suitable to participate in promotional activities of the faculty. A statistically significant difference was also identified in the domain of acquired knowledge value. Female students showed a higher level of satisfaction with acquired knowledge, which also has the following practical implications: first, female students are better faculty ambassadors in the public than male students, secondly, exploring the causes of lower male students satisfaction can contribute to the improvement of the curriculum.

In general, the obtained results indicate a need to differentiate CRM approaches in the female and male population of students in order to achieve a higher level of satisfaction of existing students. The difference in attitudes between students of graduate and master studies has not been established which suggests that no differentiation of CRM approach is needed in relation to the level of studies.

Future research will focus on determining the causes of the stated differences in the attitudes of female and male students, as well as identifying contextual variables that can affect changing attitudes.

\section{References}

Badwan, J. J., Al Shobaki, M. J., Naser, S. S. A., \& Amuna, Y. M. A. (2017). Adopting technology for customer relationship management in higher educational institutions. International Journal of Engineering and Information Systems (IJEAIS), 1(1), 20-28.

Berkowit, Z. (2006). Customer Relationship Management. 8 Common goals for a CRM Program. What are Key Drivers of Customer Satisfaction? [Online]. Retrieved from http://onlinesuccesscentre.com 
Bontis, N. (1998). Intellectual capital: an exploratory study that develops measures and models. Management decision, 36(2), 63-76.

Chen, J., \& Ching, R. K. (2005). An examination of the effects of crm practices on crm effectiveness and business performance. AMCIS 2005 Proceedings, 179-188.

Dolenec, D. (2006). Marketization in higher education policy: An analysis of higher education funding policy reforms in Western Europe between 1980 and 2000. Revija za socijalnu politiku, 13(1), $15-35$.

Fletcher, K., Wheeler, C., \& Wright, J. (1995). The role and status of UK database marketing. In Relationship marketing for competitive advantage: winning and keeping customers (pp. 278-293). Butterworth-Heinemann.

Grönroos, C. (1996). Relationship marketing: strategic and tactical implications. Management decision, 34(3), 5-14.

Gupta, P., Seetharaman, A., \& Raj, J. R. (2013). The usage and adoption of cloud computing by small and medium businesses. International Journal of Information Management, 33(5), 861-874.

Karakostas, B., Kardaras, D., \& Papathanassiou, E. (2005). The state of CRM adoption by the financial services in the UK: an empirical investigation. Information \& Management, 42(6), 853-863.

Kotler, P. (1997). Marketing Management Analysis, Planning, Implementation and Control, Practice Hall International. Inc. Upper Saddle River, New Jersey.

Laredo, P. (2007). Revisiting the third mission of universities: toward a renewed categorization of university activities?, Higher Education Policy, 20(4), 441-456.

McDonough, P. M. (1994). Buying and selling higher education: The social construction of the college applicant. The Journal of Higher Education, 65(4), 427-446.

Nair, C., Chan, S., \& Fang, X. (2007). A case study of CRM adoption in higher education. In Proceedings of the 2007 Information Resources Management Association International Conference, Vancouver. Retrieved from http://citeseerx. ist. psu. edu/viewdoc/download.

OECD (2008). Tertiary Education for the Knowledge Society. Oecd Thematic Review of Tertiary Education. Paris: OECD.

Ogunnaike, O., Tairat, B., \& Emmanuel, J. (2014). Customer relationship management approach and student satisfaction in higher education marketing. Journal of Competitiveness, 6(3), 49-62.

Pedro, E., Leitão, J., \& Alves, H. (2019). The intellectual capital of higher education institutions: Operationalizing measurement through a strategic prospective lens. Journal of Intellectual Capital.

Peppard, J. (2000). Customer Relationship Management in Financial Services. European Management Journal, 18(3), 312-327. http://dx.doi.org/10.1016/S0263-2373(00)00013-X

Peppers, D., \& Rogers, M. (1997). The One to One Future: Building Relationships One Customer at a Time (Будущее персонализации: построение взаимоотношений с одним клиентом).

Picton, D., \& Broderick, A. (2005). Integrated Marketing Communications. Essex: Pearson Education Limited.

Ramírez-Córcoles, Y. (2012). Towards improved information disclosure on intellectual capital in Spanish universities. Global Journal of Human-Social Science Research, 12(5).

Seeman, E. D., \& O'Hara, M. (2006). Customer relationship management in higher education: Using information systems to improve the student-school relationship. Campus-Wide Information Systems, 23(1), 24-34.

Sin, L. Y., Tse, A. C., \& Yim, F. H. (2005). CRM: conceptualization and scale development. European Journal of marketing, 39(11/12), 1264-1290

Swift, R. S. (2001). Accelerating customer relationships: Using CRM and relationship technologies. Prentice Hall Professional.

Veltri, S., Mastroleo, G., \& Schaffhauser-Linzatti, M. (2014). Measuring intellectual capital in the university sector using a fuzzy logic expert system. Knowledge Management Research \& Practice, 12(2), 175-192.

Wali, A. F., \& Wright, L. T. (2016). Customer relationship management and service quality: Influences in higher education. Journal of Customer Behaviour, 15(1), 67-79.

Wali, A.F. \& Nwokah G.N (2008). Contemporary book on services marketing. Owerri: Avan global publication.

Wang, Z., Wang, N., \& Liang, H. (2014). Knowledge sharing, intellectual capital and firm performance. Management decision, 52(2), 230-258. 